\title{
PENGEMBANGAN PERANGKAT PEMBELAJARAN DENGAN PENDEKATAN PENGAJUAN MASALAH PADA MATERI PERBANDINGAN DAN SKALA DI KELAS V SD
}

\author{
Siyamtini ${ }^{1}$, Siti Maghfiroton Amin $^{2}$, Tatag Yuli Eko Siswono ${ }^{3}$ \\ ${ }^{1}$ Mahasiswa Program Pascasarjana, Prodi Pendidikan Dasar, Universitas Negeri Surabaya, \\ ${ }^{2 \& 3}$ Dosen Pascasarjana, Prodi Pendidikan Dasar, Universitas Negeri Surabaya \\ e-mail: siyamtini198@gmail.com
}

Received : $\quad$ Maret 2019

Reviewed: April 2019

Accepted : $\quad$ Mei 2019

Published : Mei 2019
ABSTRACT

This research aims to produce a learning set and to describe its effectiveness trought a good problem posing approach problems in comparison and scale materials grade 5 Elementary School. This is research and development study which uses Plomp model. The model includes five phases: a preliminary investigation, design, contruction, test, evaluation, and revision, and implementation. Furthermore, the learning set producedis leson plans, worksheets, and test. The subjects were students of grade 5 SDN Erogemiwang Kebumen in the academic year 2015/2016. The data were obtained from the assessor, the observation of the teacher's activity in managing teaching learning process and student activities, the results of the questionnaire, and tes score. The technique analysis was using data validation analysis, observation analysis, and test analysis. The result show that the developed learning set meet the criteria: (1) valid, in which the assessor marks 3.13 for good learning sets and test in valid, reliable, and sensitive (2) practical, the teacher's ability is good in which the obtains 4.22 and the students are in which they reach $86.24 \%$ for the activity in experimental class, (3) effective, which is demonstrated by: (a) the teacher's is good with 4.22 poin in experimental class and 4.17 in control class. (b) the students are active in which they obtain $86.24 \%$ for their activity in experimental class and $87.85 \%$ in controlclass, (c) the students respons reach $92.8 \%$ in experimental class and $92.5 \%$ in control class, (d) the learning outcomes achieve 100\% in experimental class tests and $95 \%$ in control class. Based on the analysis, it can be concluded that developed learning set is good and problem posing approach in comparisons and scale material effective.

Key Words:learning set, problem posing, comparisons and scale.

\section{ABSTRAK}

Penelitian ini bertujuan untuk menghasilkan perangkat pembelajaran dengan pendekatan pengajuan masalah yang baik dan mendeskripsikan keefektifan pembelajaran dengan pendekatan pengajuan masalah pada materi perbandingan dan skala di kelas V SD. Penelitian ini merupakan penelitian pengembangan yang menggunakan model pengembangan Plomp. Model Plomp yang meliputi 5 tahap yaitu tahap investigasi awal, tahap perancangan realisasi/konstruksi, tahap tes, evaluasi, dan revisi, dan tahap implementasi. Perangkat yang dihasilkan meliputi: RPP, LKS, dan THB. Subjek penelitian ini adalah siswa kelas V SDN Erogemiwang Kebumen tahun pelajaran 2015/2016. Pada penelitian ini, data diperoleh dari hasil penilaian perangkat oleh validator, hasil observasi kemampuan guru mengelola pembelajaran, hasil observasi aktivitas siswa, hasil angket respons siswa, dan nilai tes hasil belajar. Teknik analisis data yang digunakan adalah analisis data validasi, analisis data observasi, dan analisis tes hasil belajar. Hasil Penelitian menunjukkan perangkat yang dikembangkan memenuhi kriteria : (1) valid, di mana penilaian validator terhadap perangkat pembelajaran berkategori baik dengan nilai 3,13 dan THB valid, reliabel, dan sensistif (2) praktis, hal ini ditunjukkan oleh kemampuan guru dalam mengelola pembelajaran berkategori baik dengan nilai 4,22 dan aktivitas siswa dalam pembelajaran berkategori aktif dengan persentase mencapai 
86,24\% di kelas uji coba dan, (3) efektif, ditunjukkan oleh: (a) kemampuan guru dalam mengelola pembelajaran berkategori baik dengan nilai 4,22 di kelas ujicoba dan 4,17 di kelas implementasi, (b) aktivitas siswa dalam pembelajaran berkategori aktif dengan persentase mencapai $86,24 \%$ di kelas uji coba dan 87,85\% di kelas implementasi, (c) respon positif siswa berkategori sangat positif dengan persentase mencapai 92,8\% di kelas uji coba dan 92,5 di kelas implementasi, (d) ketuntasan hasil belajar secara klasikal tercapai dengan persentase mencapai $100 \%$ di kelas uji coba dan $95 \%$ di kelas implementasi. Berdasarkan hasil analisis data, dapat disimpulkan bahwa perangkat pembelajaran yang dikembangkan berkualitas baik dan pembelajaran dengan pendekatan pengajuan masalah pada materi perbandingan dan skala efektif.

Kata Kunci: perangkat pembelajaran, pengajuan masalah, perbandingan dan skala.

\section{PENDAHULUAN}

Pembelajaran adalah suatu proses interaksi siswa dengan guru dan sumber belajar dalam suatu lingkungan belajar. Melalui pembelajaran siswa akan mendapatkan pengalaman belajar. Dalam Undang-undang Sistem Pendidikan Nasional (UUSPN) nomor 20 tahun 2003 pasal 1 dijelaskan bahwa pembelajaran adalah proses interaksi peserta didik dengan pendidik dan sumber belajar pada suatu lingkungan belajar. Menurut pendapat Putra (2013:16), pembelajaran adalah interaksi dua arah antara guru dan siswa, serta teori dan praktik. Pembelajaran juga merupakan suatu proses perubahan tingkah laku yang diperoleh melalui pengalaman individu yang bersangkutan (Asrori, 2007:6).

Untuk mendapatkan pengalaman belajar yang banyak, peserta didik sebaiknya dilibatkan dalam pembelajaran aktif. Menurut Warsono dan Haryanto (2012:12), pembelajaran aktif didefinisikan sebagai metode pembelajaran yang melibatkan siswa secara aktif dalam proses pembelajaran. Pembelajaran aktif mengondisikan siswa agar mendapatkan pengalaman belajar yang bermakna. Pembelajaran aktif melibatkan siswa untuk melakukan sesuatu dan berpikir tentang sesuatu yang dilakukannya. Oleh sebab itu, pembelajaran tidak cukup hanya dengan memberitahukan akan tetapi mendorong peserta didik untuk melakukan suatu proses melalui berbagai aktivitas yang mendukung pencapaian kompetensi.

Pembelajaran matematika merupakan salah satu pembelajaran yang terjadi di Sekolah Dasar. Pembelajaran matematika berupaya untuk membantu siswa membangun konsep-konsep atau prinsip-prinsip matematika dengan kemampuannnya sendiri. Melalui pembelajaran matematika diharapkan siswa mendapat pengalamanpengalaman yang dapat membantu mereka dalam membangun konsep matematika. Namun kenyataannya pembelajaran matematika yang diterapkan di SD umumnya masih bersifat konvensional. Dari hasil wawancara di SDN 3 Krakal diperoleh informasi bahwa para guru mengajar matematika dengan cara ceramah penjelasan materi kemudian siswa diberi contoh dan mengerjakan soal latihan. Mereka belum menerapkan pembelajaran aktif dengan alasan waktu yang diperlukan sangat terbatas dan materi pelajaran yang perlu diberikan sangat banyak. Tentu saja hal ini membatasi peserta didik untuk aktif mendapatkan pengalaman dalam pembelajaran.

Para guru di daerah peneliti umumnya mengajar dengan RPP cetak yang beredar di tingkat kecamatan. Masih jarang guru yang menggunakan RPP hasil karya sendiri. Mereka menggunakan RPP cetak dengan alasan praktis dengan disesuaikan identitas sekolah masingmasing. Dengan RPP cetak yang tersedia, jarang juga guru membuat lembar LKS sendiri. Hal yang sering dilakukan adalah membuat soal ulangan harian di buku untuk keperluan administrasi.

Sementara itu hasil belajar matematika siswa kelas V yang dicapai di SDN 3 Krakal Kebumen masih rendah. Data ini diperoleh dari hasil dokumentasi di SDN 3 Krakal Kebumen pada semester genap tahun ajaran 2014/2015. Dilihat dari hasil dokumentasi diperoleh nilai rata-rata ulangan harian matematika kelas $\mathrm{V}$ pada kompetensi dasar menyelesaikan masalah perbandingan dan skala dari 31 siswa hanya mencapai 59,84. Siswa yang mencapai ketuntasan belajar hanya 13 anak atau $42 \%$.

Hasil analisis soal try out Ujian Nasional (UN) dari Kabupaten menunjukkan banyak siswa yang salah dalam menjawab soal tentang perbandingan dan skala. Berdasarkan data analisis selama 3 tahun terakhir menunjukkan bahwa masih banyak siswa yang kesulitan menyelesaikan soal tentang perbandingan dan skala. Siswa banyak yang lupa cara menyelesaikan soal tersebut apalagi soal yang menggunakan rumus pada skala. Ketika menerapkan rumus pada skala juga masih ada kesulitan dalam mengubah satuan jarak. Tentu saja hal ini menjadi 
hambatan dalam menyelesaikan soal tentang perbandingan dan skala.

Berdasarkan hal tersebut, siswa perlu dilibatkan secara aktif dalam aktivitas pembelajaran. Siswa dilatih untuk memahami masalah sehari-hari ke dalam matematika dan menyelesaikannya. Siswa juga dilatih untuk merumuskan suatu masalah berdasarkan informasi yang diberikan agar mereka lebih peka dalam memahami materi perbandingan dan skala. Siswa dapat bekerja sama dengan kelompoknya dalam menyelesaikan tugas pada Lembar Kegiatan Siswa (LKS).

Pembelajaran dengan pendekatan pengajuan masalah (soal) merupakan salah satu pendekatan pembelajaran yang baik. Pembelajaran dengan pendekatan pengajuan masalah (soal) dapat mengaktifkan siswa dan mengembangkan kemampuan berpikir kreatif siswa dalam menyelesaikan suatu masalah. Dengan membiasakan siswa dalam merumuskan, menghadapi dan menyelesaikan masalah (soal) diharapkan siswa dapat menguasai suatu konsep dengan lebih baik sehingga pemahaman siswa terhadap suatu masalah akan lebih baik. Menurut Nasoetion (dalam Siswono, 2008:49), pengajuan masalah (soal) merupakan tugas kegiatan yang mengarah pada sikap kritis dan kreatif. Sebab dalam pengajuan masalah siswa diminta untuk membuat pertanyaan dari informasi yang diberikan. Bertanya itu sendiri merupakan pangkal dari semua kreasi. Orang yang mempunyai kemampuan mencipta (berkreasi) bisa dikatakan memiliki sikap kreatif.

Herawati (2010) berpendapat bahwa pembelajaran dengan pendekatan problem posing adalah pembelajaran yang menekankan pada siswa untuk membentuk/mengajukan soal berdasarkan informasi atau situasi yang diberikan. Informasi yang ada diolah dalam pikiran dan setelah dipahami maka peserta didik akan bisa mengajukan pertanyaan.

Sementara itu, dari hasil penelitian yang dilakukan oleh Haji (2011) menunjukkan bahwa penerapan pendekatan pengajuan masalah (problem posing) dalam pembelajaran matematika dapat meningkatkan hasil belajar matematika siswa bila dibandingkan dengan hasil belajar siswa yang diajar melalui pembelajaran biasa. Beberapa pendapat di atas menunjukkan pengaruh yang baik antara penggunaan pendekatan pengajuan masalah (soal) dengan kemampuan berpikir dan hasil belajar siswa.

Dengan pendekatan problem posing, peserta didik berhasil diadaptasi, contoh ketika mereka sendiri mengajukan masalah jika mereka pelajari contoh dengan metode reproduksi (membuat soal kembali). Dengan demikian, belajar dari contoh-contoh melalui reproduksi tampaknya efektif dalam domain masalah yang disamarkan sebagai tugas produksi (Kojima, Miwa, dan Matsui. 2013). Dari hasil penelitian tersebut menunjukkan keefektifan tugas mengajukan masalah yang diberikan kepada siswa dalam pembelajaran.

Hasil penelitian Hsiao, Hung, Lan, dan Jeng (2013) menunjukkan bahwa mengintegrasikan contoh bekerja dalam problem posing memiliki efek pengembangan keterampilan yang signifikan terhadap pengajuan lebih berorientasi dan masalah yang kompleks, terutama untuk masalah analitis mengacu konsep belajar atau formula. Selain itu, siswa pemula yang belum pengalaman dalam pengajuan masalah dapat mengambil manfaat dari dukungan contoh bekerja untuk meningkatkan keterampilan problem posing mereka. Dari hasil penelitian tersebut menunjukkan bahwa pengajuan masalah memiliki pengaruh baik yaitu dapat meningkatkan keterampilan siswa dalam mengajukan masalah.

Penelitian yang dilakukan oleh Kesan, Kaya, dan Guvercin (2010) menunjukkan bahwa interaksi antara guru dan siswa begitu tinggi dan siswa sangat aktif itu sebabnya guru dapat menemukan siswa berbakat dalam kemampuan matematikanya. Dengan problem posing dapat digunakan dalam proses identifikasi siswa berbakat di kalangan siswa atau untuk mengidentifikasi kemampuan matematika. Tidak hanya digunakan dalam proses identifikasi tetapi juga problem posing digunakan untuk meningkatkan dan pengembangan kemampuan matematika.

Berdasarkan uraian di atas, maka penulis tertarik untuk mengembangkan perangkat pembelajaran dengan pendekatan pengajuan masalah pada materi perbandingan dan skala untuk kelas V SD. Perangkat pembelajaran yang dikembangkan meliputi RPP (Rencana Pelaksanaan Pembelajaran), LKS (Lembar Kerja Siswa), dan lembar THB (Tes Hasl Belajar). Melalui pembelajaran dengan pengajuan masalah pada materi perbandingan dan skala, diharapkan siswa aktif dalam pembelajaran, mampu memecahkan masalah (menyelesaikan soal) dan mencapai hasil belajar yang optimal. Untuk itu, penulis merancang penelitian ini dengan judul "Pengembangan Perangkat Pembelajaran dengan Pengajuan Masalah pada Materi Perbandingan dan Skala di Kelas V SD”.

\section{KAJIAN PUSTAKA}

\section{A. Pendekatan Pengajuan Masalah}

Upu (2003:19) mengemukakan bahwa pengajuan masalah matematika merupakan reaksi siswa terhadap situasi yang telah disediakan guru. Reaksi tersebut berupa respons dalam bentuk pernyataan, pertanyaan non matematika atau pertanyaan matematika, terlepas dari 
apakah pertanyaan matematika tersebut pada akhirnya dapat dipecahkan atau tidak. Pertanyaan tersebut mungkin berkaitan dengan situasi yang diberikan atau merupakan pengembangan dari situasi lain.

Polya (dalam Haji, 2011) berpendapat bahwa dalam pembelajaran matematika, problem posing merupakan suatu pendekatan yang menekankan pada perumusan soal. Dengan bimbingan guru, siswa merumuskan soal dalam rangka memecahkan soal yang lebih komplek. Menurut Brown dan Walter (dalam Haji, 2011), menyatakan bahwa soal dapat dirumuskan melalui beberapa situasi, antara lain: gambar, benda manipulatif, permainan, teorema/konsep, alat peraga, soal, dan solusi dari suatu soal.

Menurut Irwan (2011), problem posing merupakan suatu bentuk pendekatan yang menekankan pada perumusan soal dan menyelesaikannya, yang dapat mengembangkan kemampuan berpikir matematis atau menggunakan pola pikir matematis.

Pendekatan problem posing merupakan suatu pendekatan pembelajaran yang menekankan pada kegiatan pengajuan masalah yang dimulai dengan pemberian sebuah keadaan atau situasi oleh guru, siswa kemudian diminta untuk mengajukan pertanyaan berdasar pada situasi yang diberikan dengan mengacu kepada tujuan pembelajaran sehingga pertanyaan yang muncul tidak keluar dari materi yang sedang diajarkan (Widnya, Suwatra, dan Murda. 2013).

Kasturi, Dafik, dan Darojat (2015) berpendapat bahwa Pendekatan pembelajaran problem posing adalah suatu pendekatan pembelajaran yang memberikan kesempatan kepada siswa untuk mengajukan/membuat soal sendiri berdasarkan situasi atau informasi yang diberikan, kemudian menyelesaikannya.

Menurut Silver (dalam Irwan, 2011), dalam ranah pendidikan matematika, problem posing mempunyai tiga pengertian, yaitu: 1) problem posing adalah perumusan soal sederhana atau perumusan ulang soal yang ada dengan beberapa perubahan agar lebih sederhana dan dapat dipahami dalam rangka memecahkan soal yang rumit (problem posing sebagai salah satu langkah problem solving), 2) problem posing adalah perumusan soal yang berkaitan dengan syarat-syarat pada soal yang telah dipecahkan dalam rangka mencari alternatif pemecahan lain atau mengkaji kembali langkah problem solving yang telah dilakukan, dan 3) problem posing adalah merumuskan atau membuat soal dari situasi yang diberikan.
Menurut Silver (dalam Siswono,2008: 40), pengajuan soal (problem posing) diaplikasikan pada tiga bentuk aktivitas kognitif matematika yang bereda yaitu:

1. Pengajuan pre-solusi (presolution posing) yaitu seorang siswa membuat soal dari situasi yang diadakan

2. Pengajuan di dalam solusi (within-solution posing) yaitu seorang siswa merumuskan ulang soal seperti yang telah diselesaikan

3. Pengajuan setelah solusi (post solution posing), yaitu seorang siswa memodifikasi tujuan atau kondisi soal yang sudah diselesaikan untuk membuat soal yang baru.

Pembelajaran dengan pendekatan pengajuan masalah mengacu pada langkah-langkah pengajuan masalah. Langkah-langkah pengajuan masalah yang ditelah dirumuskan oleh Siswono (2008:74) yaitu sebagai berikut :

1. Menyampaikan tujuan dan mempersiapkan siswa.

2. Mengorientasikan siswa pada masalah melalui pemecahan atau pengajuan masalah dan mengorganisasikan siswa untuk belajar.

3. Membimbing penyelesaian secara individual maupun kelompok.

4. Menyajikan hasil penyelesaian pemecahan dan pengajuan masalah.

5. Memeriksa pemahaman dan memberikan umpan balik sebagai evaluasi.

Dari beberapa pengertian pengajuan masalah yang dikemukakan di atas dapat disimpulkan bahwa pendekatan pengajuan masalah/soal (problem posing) merupakan pendekatan dalam pembelajaran dengan cara memberi tugas kepada siswa untuk membuat masalah/soal berdasarkan situasi yang ada atau yang diberikan dan menyelesaikan soal tersebut. Situasi yang diberikan dalam pembelajaran dapat berupa gambar, cerita, atau informasi lain yang berkaitan dengan materi pembelajaran. Dalam pengembangan perangkat pembelajaran pada penelitian ini menggunakan pendekatan pengajuan masalah tipe pengajuan pre-solusi (presolution posing) yaitu seorang siswa membuat soal dari situasi yang diadakan.

\section{B. Perbandingan dan Skala}

Menurut Saepudin, Babudin, Mulyadi, \& Adang (2009:141), perbandingan merupakan pernyataan bagian dari jumlah atau kumpulan tertentu. Cara menyederhanakan perbandingan sama halnya dengan menyederhanakan pecahan, yaitu dibagi dengan bilangan yang sama. Contoh 3:7 dapat ditulis $\frac{3}{7}$ (dibaca 3 berbanding 7). Menurut Sugiono dan Gunarto (2007: 141), suatu perbandingan dapat ditulis dalam bentuk pecahan. 
Contohnya a:b dapat ditulis $\frac{a}{b}$. Suatu perbandingan harus ditulis dalam bentuk paling sederhana yaitu dengan membagi kedua bilangan tersebut dengan FPB (Faktor Persekutuan Terbesar).

Jadi perbandingan adalah pernyataan bagian dari jumlah atau kumpulan tertentu. Perbandingan ditulis dalam bentuk a:b atau $\frac{a}{b}$ (dibaca a berbanding b). Perbandingan ditulis dalam bentuk paling sederhana yaitu dengan cara membagi dengan bilangan yang sama atau FPB (Faktor Persekutuan Terbesar).

Skala (dalam KBBI, 2008: 1323) adalah perbandingan ukuran besarnya gambar dan sebagainya dengan keadaan yang sebenarnya. Menurut Astuti dan Sunardi (2009: 121), skala digunakan untuk memperkecil ukuran dari jarak sebenarnya. Skala biasanya dipakai dalam penulisan peta atau denah. Contoh dalam gambar kebun tertulis skala 1:1500 artinya $1 \mathrm{~cm}$ pada gambarmewakili $1500 \mathrm{~cm}=15 \mathrm{~m}$ pada ukuran sebenarnya. Jadi dapat disimpulkan bahwa skala adalah hasil perbandingan jarak peta/gambar/denah dengan dengan jarak yang sebenarnya.

\section{Perangkat Pembelajaran}

Perangkat pembelajaran adalah perangkat yang dipergunakan dalam proses pembelajaran (Trianto, 2007: 68). Menurut Ibrahim (2003:3), perangkat pembelajaran yang diperlukan guru dalam mengelola proses belajar mengajar meliputi silabus, Rencana Pelaksanaan Pembelajaran (RPP), Lembar Kegiatan Siswa (LKS), Instrumen Evaluasi atau Tes Hasil Belajar (THB), media pembelajaran, dan buku siswa. Dengan demikian perangkat pembelajaran adalah perangkat yang diperlukan dalam kegiatan pembelajaran. Perangkat pembelajaran yang disusun dalam penelitian ini adalah Rencana Pelaksanaan Pembelajaran (RPP), Lembar Kegiatan Siswa (LKS), dan Tes Hasil Belajar (THB).

\section{Perangkat Pembelajaran yang Baik.}

Perangkat pembelajaran yang baik adalah suatu perangkat pembelajaran yang menunjang pembelajaran sehingga tujuan yang diharapkan dalam pembelajaran dapat tercapai (Khabibah, 2006:89). Menurut Plomp \& Nieveen (2007: 267), kriteria perangkat yang baik adalah valid, praktis, dan efektif. Perangkat pembelajaran dikatakan valid jika memenuhi validasi isi dan validasi konstruk. Kemudian perangkat pembelajaran dikatakan praktis jika perangkat tersebut dinyatakan layak digunakan dan mudah diterapkan bagi guru dan siswa. Hal tersebut dapat diketahui dari keterlaksanaan RPP meliputi kemampuan guru dalam mengelola pembelajaran baik dan aktivitas siswa dalam pembelajaran baik. Selanjutnya perangkat pembelajaran dikatakan efektif jika kemampuan guru dalam mengelola pembelajaran sesuai dengan apa yang direncanakan. Kemudian siswa dapat melaksanakan kegiatan pembelajaran yang dirancang. Hai ini dapat dilihat dari aktivitas siswa dalam pembelajaran. siswa juga memberikan respons yang baik terhadap pembelajaran dan perangkat yang dikembangkan memberi hasil sesuai dengan harapan. Hasil yang dimaksud adalah ketercapaian ketuntasan belajar.

\section{E. Keefektifan Pembelajaran}

Dalam Kamus Besar Bahasa Indonesia (2008:352) keefektifan berarti keberhasilan (tentang usaha, tindakan). Maryati (2014) berpendapat bahwa aktivitas pembelajaran adalah ukuran keberhasilan suatu pembelajaran.

Menurut Slavin (1994:310), keefektifan pembelajaran terdiri dari empat indikator yaitu kualitas pembelajaran (quality of intruction), kesesuaian tingkat pembelajaran (approriate levels of instruction), insentif (incentif), dan waktu (time). Berikut uraian empat indikator tersebut:

Berdasarkan uraian di atas keefektifan pembelajaran adalah keberhasilan suatu pembelajaran yangdapat diukur dengan indikator keefektifan pembelajaran. Dari uraian indikator keefektifan pembelajaran yang dikemukakan di atas, maka indikator keefektifan pembelajaran dalam penelitian ini antara lain:

1. Kemampuan guru dalam mengelola pembelajaran dengan nilai $\mathrm{TKG} \geq 4$

2. Aktivitas siswa dalam pembelajaran dengan persentase $\geq 80 \%$

3. Respons siswa terhadap pembelajaran dengan persentase $\geq 70 \%$

4. Ketuntasan hasil belajar secara klasikal tercapai dengan persentase $\geq 80 \%$

\section{F. Model Pengembangan Plomp}

Pengembangan perangkat pembelajaran pada penelitian ini mengikuti model pengembangan yang dikemukakan oleh Plomp (dalam Ahdhianto, 2013). Model ini dipilih karena langkah-langkah pengembangannya berkaitan dengan pendidikan. Tahapan-tahapan pengembangannya sederhana, sistematis dan mudah dipahami. Model ini terdiri dari 5 tahap yaitu (1) tahap investigasi awal (prelimenary investigation), (2) tahap desain (design), (3) tahap realisasi/ konstruksi (realization/construction), (4) tahap tes, evaluasi dan revisi 
(test, evaluation, and revision), dan (5) tahap implementasi (implementation).

\section{G. Penelitian yang Relevan}

Adapun penelitian yang relevan tentang pendekatan pengajuan masalah (problem posing) adalah sebagai berikut:

1. Penelitian Hermat (2013) dengan judul "Pengembangan Perangkat Pembelajaran Kooperatif Tipe Think Pair Sharedengan Pendekatan Pengajuan Soal pada Materi Trigonometri di Kelas X SMA Negeri 1 Sangkurilang " menunjukkan hasil bahwa rata-rata nilai kemampuan guru mengelola pembelajaran tiap RPP $\geq 3,25$, persentase aktivitas siswa untuk tiap kategori pengamatan dan tiap pertemuan berada pada kriteria batasan keefektifan pembelajaran, persentase jawaban positif untuk setiap aspek yang ditanyakan pada angket respons siswa > $80 \%$, tes hasil belajar memenuhi kriteria valid dengan tingkat validitas tinggi, reliabel dengan koefisien reliabilitas tes 0,797 , dan sensitif dengan sensitivitas tiap butir soal >0,50. Dalam penelitian tersebut menggunakan pembelajaran kooperatif tipe Think Pair Share, sedangkan pembelajaran dalam penelitian ini mengacu pada langkah-langkah pengajuan masalah.

2. Penelitian Ma'rufi, Ilyas \& Fitriani (2014) yang berjudul "Pengembangan Bahan Ajar Matematika Berbasis Problem Posing dengan Scaffolding Metakognitif pada SMPN Kota Palopo" menunjukkan hasil uji coba pertama yaitu: (1) perangkat pembelajaran sudah praktis, tetapi masih ada saran pengamat perlu diperhatikan untuk meningkatkan kepraktisan perangkat, (2) perangkat pembelajaran belum efektif, karena ketuntasan klasikal belum tercapai dan aktivitas siswa belum sesuai yang diharapkan, kemampuan guru mengelola pembelajaran dalam kategori tinggi dan respons siswa dalam kategori positif. Hasil analisis ini digunakan merevisi perangkat sebelum dilakukan uji coba kedua. Dalam penelitian tersebut dihasilkan perangkat pembelajaran berupa bahan ajar, LKS, dan RPP. Pendekatan yang digunakan adalah problem posingdengan scaffolding Metakognitif. Sedangkan dalam penelitian ini perangkat pembelajaran yang dihasilkan berupa RPP, LKS, dan THB. Pendekatan yang digunakan dalam penelitian ini adalah pengajuan masalah tipe pengajuan pre-solusi (presolution posing).
3. Penelitian Kasturi, Dafik \& Darojat (2015) dengan judul "Pengembangan Perangkat Pembelajaran Problem Posing Berorientasi Penerapan HOTS pada Materi Kesebangunan kelas IX" menunjukkan hasil yang diperoleh yaitu skor validasi adalah 4,19 (kategori baik) , persentase rata-rata kemampuanguru dalam mengelola pembelajaran adalah $86,5 \%$ (kategori baik) , persentase rata-rata aktivitas siswa dalam belajar adalah $86,9 \%$ (kategori baik), rata-rata tanggapan siswaadalah $95,17 \%$ (sangat positif), item validitas rata-rata adalah 0,71 (tinggi) ,item reliabilitas adalah 0,80 (tinggi), dan $88,9 \%$ siswa telah tuntas, (2) hasil belajar siswa yang mengambil bagian dalam masalah belajar terkait denganpenerapan HOTS berorientasi lebih baik daripada hasil belajar siswayang diberikan pembelajaran konvensional matematika dengan materi kesebangunan. Penelitian tersebut berorientasi pada ketrampilan berpikir tingkat tinggi (Higher Order Thinking Skill atau HOTS) yang meliputi menganalisis, mengevaluasi dan mengkreasi/mencipta. Dalam memberi penilaian guru dalam mengelola pembelajaran menggunakan persentase. Sedangkan dalam penelitian ini mengacu pada pre-solusi yaitu siswa diberi kesempatan melengkapi pemecahan masalah kemudian siswa mencoba mengajukan masalah serta solusinya berdasarkan situasi yang diberikan. Penilaian guru dalam mengelola pembelajaran menggunakan kriteria $1-5$.

4. Penelitian Muriadi, Parta \& Muksar (2013) berjudul "Pengembangan Perangkat Pembelajaran Matematika Tipe Problem Posing untuk Meningkatkan Penguasaan Konsep Operasi Bentuk Aljabar”. Hasil Penelitian menunjukkan bahwa kevalidan Rencana Pelaksanaan pembelajaran (RPP) ditunjukkan oleh persentase rata-rata semua indikator dari ketiga validator yaitu $91,41 \%$, persentase rata-rata ketercapaian dari observasi keterlaksanaan perangkat pembelajaran dan aktivitas guru dalam pembelajaran, serta observasi keterlaksanaan perangkat pembelajaran dan aktivitas siswa dalam pembelajaran yaitu $93,91 \%$ dan $94,01 \%$, Tes Penguasaan Bahan Ajar (TPBA) mempunyai nilai rata-rata adalah 92,00, dan ketuntasan secara klasikal termasuk kategori tuntas, karena jumlah siswa yang telah tuntas sebesar $100 \%$.

Dalam penelitian tersebut menggunakan model pengembangan Plomp. Namun fase implementasi tidak dilakukan dengan alasan penelitian berorientasi 
pada produk saja. Dalam menilai validasi perangkat menggunakan persentase. Dalam penelitian ini juga mengacu model Plomp sampai fase implementasi. Dalam menilai perangkat menggunakan kriteria 1-4.

5. Penelitian oleh Subagyo, Mulyono \& Sukestiyarno (2013) berjudul "Pembelajaran Matematika Bermuatan Pendidikan Karakter dengan Pendekatan Problem Posing Melalui Laboratorium Teenzania". Hasil penelitian menunjukkkan bahwa hasil validasi silabus 4,20; RPP 4,30; buku siswa 4,22; dan LKS 4,19, dengan skor maksimal 5. Jadi semua memenuhi kriteria valid. Perangkat pembelajaran praktis yang ditandai oleh responss positif siswa 83,74\%, skor responss guru 45 dari skor maksimal 60 dengan kriteria baik, dan skor kemampuan guru mengelola pembelajaran 25,75 dari skor maksimal 36 dengan kriteria baik. Pembelajaran efektif yang ditandai oleh rata-rata prestasi belajar 81,38 memenuhi batas KKM 75 dan $80 \%$ lebih siswa mendapatkan nilai lebih besar dari KKM, rata-rata prestasi belajar kelas ekperimen 81,38 lebih besar dari kelas kontrol 75,31, dan aktivitas serta keterampilan proses berpengaruh positif terhadap prestasi belajar $83,1 \%$. Penelitian tersebut memanfaatkan laboratorium Teenzania(Teeneger-Zania) yang dibentuk sebagai laboratorium mini yang menyerupai transaksi kejadian, atau bentuk transaksi langsung di lapangan dengan populasi siswa SMA. Dalam menilai validasi perangkat menggunakan kriteria 1-5. Sedangkan dalam penelitian ini siswa berdiskusi kelompok melengkapi tugas pada LKS. Penilaian validasi perangkat menggunakan kriteria 1-4.

\section{H. Kerangka Berpikir}

Berdasarkan latar belakang masalah, peneliti mengembangkan perangkat pembelajaran sebagai solusinya. Perangkat pembelajaran yang dikembangkan menggunakan pendekatan pengajuan masalah tipe presolusi (presolution posing) pada materi perbandingan dan skala di kelas V SD . Perangkat pembelajaran yang dikembangkan meliputi RPP, LKS, danTHB. Pengembangan perangkat pembelajaran ini sesuai dengan langkah-langkah pengembangan yang dikemukakan oleh Plomp sehingga diharapkan pembelajaran menjadi efektif.

\section{METODE}

Penelitian ini merupakan penelitian pengembangan, dengan model Plomp. Subjek penelitian ini adalah siswa kelas V SDN Erogemiwang Kebumen tahun pelajaran 2015/2016.
Pengembangan perangkat pembelajaran pada penelitian ini mengikuti model pengembangan yang dikemukakan oleh Plomp.

Perangkat pembelajaran yang dihasilkan akan diujicobakan di kelas setelah dinyatakan valid oleh validator. Peneliti melaksanakan uji coba untuk melihat keefektifan pembelajaran matematika pada siswa kelas $\mathrm{V}$ SD menggunakan perangkat pembelajaran dengan pendekatan pengajuan masalah yang telah dikembangkan.

Data yang telah diperoleh kemudian dianalisis secara deskripsi kualitatif dan deskripsi kuantitatif. Adapun metode pengumpulan data yang digunakan antara lain validasi, observasi, tes, dan angket.

\section{HASIL DAN PEMBAHASAN}

\section{Kelayakan}

Validitas RPP dari hasil penilaian validator I adalah 3,00. Validitas RPP dari hasil penilaian validator II adalah 3,36. Dari hasil validitas RPP dari validator I dan validaor II diperoleh hasil validitas RPP adalah 3, 18. Kedua validator menyimpulkan bahwa RPP valid dan dapat digunakan dengan sedikit revisi.

Validitas LKS dari hasil penilaian validator I adalah 3,00. Validitas LKS dari hasil penilaian validator II adalah 3,17. Dari hasil validitas LKS dari validator I dan validaor II diperoleh hasil validitas LKS adalah 3, 09. Kedua validator menyimpulkann bahwa LKS valid dan dapat digunakan dengan sedikit revisi.

Validitas THB dari hasil penilaian validator I adalah 3,00. Validitas THB dari hasil penilaian validator II adalah 3,25. Dari hasil validitasTHB dari validator I dan validaor II diperoleh hasil validitas THB adalah 3,13. Kedua validator menyimpulkann bahwa THB valid dan dapat digunakan dengan sedikit revisi. Dari hasil validitas RPP, LKS, dan THB diperoleh validitas perangkat adalah 3,13 (kategori baik).

Nilai Tingkat Kemampuan Guru (TKG) pada pertemuan I adalah 4,17. Nilai TKG pada pertemuan II dan III masing-masing adalah 4,25. Jadi secara keseluruhan nilai TKG di kelas uji coba/VA adalah 4,22 (kategori baik). Aktivitas siswa pada setiap pertemuan masing-masing mencapai $83,29 \%$, 86,43\%, dan 89,00\%. Jadi secara keseluruhan Aktivitas siswa dalam pembelajaran di kelas uji coba/VA mencapai 86,24\% (kategori aktif).

\section{Keefektifan}

Keefektifan perangkat pembelajaran yang dikembangkan dilihat dari respons siswa dalam pembelajaran dan hasil belajar siswa. Hasil angket respons siswa dalam pembelajaran menunjukkan bahwa respons 
positif siswa mencapai $92,8 \%$ dalam kategori sangat positif. Tes hasil belajar memenuhi kriteria valid, reliabel, dan sensitif. THB valid dengan koefisien validitas nomor soal 1 adalah 0,525 (cukup), nomor soal 2 adalah 0,503 (cukup), nomor soal 3 adalah 0,602 (tinggi), dan nomor soal 3 adalah 0,791 (tinggi). THB reliabel dengan nilai koefisien reliabilitas 0,429 pada kategori sedang. Setiap butir soal THB adalah sensitif dengan sensitivitas nomor soal 1 adalah 0,89 (sensitif), nomor soal 2 adalah 0,44 (sensitif), soal nomor 3 adalah 0,78 (sensitif), dan soal nomor 4 adalah 0,27 (sensitif). Ketuntasan hasil belajar secara klasikal tercapai dengan persentase mencapai $100 \%$.

Keefektifan pembelajaran diperoleh data dari hasil penelitian di kelas implementasi yaitu kelas VB. Hasil pengamatan pada kemampuan guru dalam mengelola pembelajaran di kelas VB mendapatkan nilai 4,17. Hal ini menunjukkan bahwa kemampuan guru dalam mengelola pembelajaran berada pada kategori baik. Hasil pengamatan aktivitas siswa di kelas VB menunjukkan persentase aktivitas siswa mencapai 87,85\%. Dengan demikian, aktivitas siswa dalam pembelajaran berada pada kategori aktif. Hasil angket yang diisi oleh siswa dikelas VB menunjukkan persentase respon positif siswa mencapai 92,5\%. Dengan demikian, respons positif siswa berada pada kategori sangat positif.

Hasil belajar siswa pada materi perbandingan dan skala di kelas VB menunjukkan bahwa siswa yang tuntas belajar adalah 19 siswa atau mencapai 95\%. Ada 1 siswa yang tidak tuntas KKM. Hal ini menunjukkan bahwa ketuntasan belajar tercapai.

Sesuai dengan hasil analisis data perangkat pembelajaran, penelitian uji coba yang dilakukan sudah menunjukkan bahwa perangkat yang dikembangkan layak sesuai kriteria valid, praktis, dan efektif sesuai dengan pendapat Plomp dan Nieveen. Menurut Plomp \& Nieveen (2007: 267), kriteria perangkat yang baik adalah valid, praktis, dan efektif. (1) valid, di mana penilaian validator terhadap perangkat pembelajaran berkategori baik dengan nilai 3,13 (hasil validitas perangkat ini sesuai dengan kriteria yang diadopsi dari hasil penelitian yang dilakukan oleh Khabibah (2006) dan THB valid, reliabel, dan sensistif (2) praktis, hal ini ditunjukkan oleh kemampuan guru dalam mengelola pembelajaran berkategori baik dengan skor rata-rata 4,22 (hasil kemampuan guru mengelola pembelajaran ini sesuai kriteria yang diadopsi dari penelitian yang dilakukan oleh Hobri, 2010). dan aktivitas siswa dalam pembelajaran berkategori aktif dengan persentase mencapai 86,24\% (sejalan dengan kriteria hasil penelitian yang dilakukan oleh Khabibah, 2006), (3) efektif, ditunjukkan oleh kemampuan guru dalam mengelola pembelajaran berkategori baik dengan nilai 4,22 (hasil kemampuan guru mengelola pembelajaran ini sesuai kriteria yang diadopsi dari penelitian yang dilakukan oleh Hobri, 2010), aktivitas siswa dalam pembelajaran berkategori aktif dengan persentase mencapai $86,24 \%$ (sejalan dengan kriteria hasil penelitian yang dilakukan oleh Khabibah, 2006), respon positif siswa berkategori sangat positif dengan persentase mencapai 92,8\% (sejalan dengan penelitian yang dilakukakan oleh Kasturi, 2015), dan ketuntasan hasil belajar secara klasikal tercapai dengan persentase mencapai $100 \%$.

Langkah- langkah pembelajaran yang dilakukan dalam penelitian ini telah mengikuti langkah-langkah pengajuan masalah yang ditelah dirumuskan oleh Siswono (2008:74) yaitu sebagai berikut : (1) menyampaikan tujuan dan mempersiapkan siswa, (2) mengorientasikan siswa pada masalah melalui pemecahan atau pengajuan masalah dan mengorganisasikan siswa untuk belajar, (3) membimbing penyelesaian secara individual maupun kelompok, (4) menyajikan hasil penyelesaian pemecahan dan pengajuan masalah, dan (5) memeriksa pemahaman dan memberikan umpan balik sebagai evaluasi.

\section{SIMPULAN DAN SARAN}

Perangkat pembelajaran yang dikembangkan memenuhi kriteria: (1) valid, di mana penilaian validator terhadap perangkat pembelajaran berkategori baik dengan nilai 3,13 dan THB valid, reliabel, dan sensistif (2) praktis, hal ini ditunjukkan oleh kemampuan guru dalam mengelola pembelajaran berkategori baik dengan nilai 4,22 dan aktivitas siswa dalam pembelajaran berkategori aktif dengan persentase mencapai 86,24\%, (3) efektif, ditunjukkan oleh kemampuan guru dalam mengelola pembelajaran berkategori baik dengan nilai 4,22, aktivitas siswa dalam pembelajaran berkategori aktif dengan persentase mencapai $86,24 \%$, respon positif siswa berkategori sangat positif dengan persentase mencapai $92,8 \%$, dan ketuntasan hasil belajar secara klasikal tercapai dengan persentase mencapai $100 \%$.

Pembelajaran menggunakan perangkat pembelajaran dengan pengajuan masalah pada materi perbandingan dan skala efektif . Hal ini ditunjukkan oleh hasil pengamatan di kelas implementasi: (1) kemampuan guru dalam mengelola pembelajaran berkategori baik dengan nilai 4,17, (2) aktivitas siswa dalam pembelajaran berkategori aktif dengan persentase mencapai 87,85\%, (3) respons positif siswa terhadap pembelajaran berkategori sangat positif dengan persentase mencapai 92,5\%, (4) ketuntasan hasil belajar secara klasikal tercapai dengan persentase $95 \%$. 
Dengan memperhatikan simpulan, peneliti menyarankan hal-hal berikut:

1. Guru dapat menggunakan perangkat pembelajaran berbasispengajuan masalah dengan metode diskusi sebagai alternatif perangkat pembelajaran pada materi perbandingan dan skala.

2. Guru dapat menggunakan pengajuan masalah dengan metode diskusi dalam pembelajaran dengan materi yang lain.

\section{DAFTAR PUSTAKA}

Ahdhianto, Erif. (2013). Pengembangan Modul Pembelajaran Geometri Bangun Datar Berbasis Teori Van Hiele untuk Siswa Kelas VI Sekolah Dasar (Tesis yang tidak dipublikasikan), Universitas Negeri Surabaya, Surabaya.

Akbar, Sa'dun. (2013). Instrumen Perangkat Pembelajaran. Bandung: PT Remaja Rosdakarya.

Arifin, Zaenal. (2012). Evaluasi Pembelajaran. Bandung: PT Remaja Rosdakarya.

Arikunto, Suharsimi. (2013). Dasar-dasar Evaluasi Pendidikan. Jakarta: Bumi Aksara.

Asrori, Mohammad. (2007). Psikologi Pembelajaran. Bandung: CV Wacana Prima.

Astuti, Lusia Tri \& P. Sunardi. (2009). Matematika untuk $S D$ Kelas $V$. Jakarta: Pusat Perbukuan Depdiknas.

Depdiknas.(2008). Kamus Besar Bahasa Indonesia. Jakarta: PT Gramedia.

Grondlund, Norman E. (1982). Constructing Achievement Test (Third Edition). Englewood Cliffs, N.J: Prentice-Hall.

Haji, Saleh. (2011). Pendekatan Problem Posing dalam Pembelajaran Matematika di Sekolah Dasar. Jurnal Kependidikan Triadik, April 2011, Volume 14, No.1

Herawati, Oktiana Dwi Putra, Rusdi Siroj, \& H.M. Djahir Basir. (2010). Pengaruh Pembelajaran Problem posing terhadap Kemampuan Pemahaman Konsep Matematika Siswa Kelas XI IPA SMA Negeri 6 Palembang. Jurnal Pendidikan Matematika Volume 4. No. 1 Juni 2010.

Hermat. (2013). Pengembangan Perangkat Pembelajaran Kooperatif Tipe Think Pair Share dengan Pendekatan Pengajuan Soal pada Materi Trigonometri di Kelas X SMA Negeri 1 Sangkulirang (Tesis yang tidak dipublikasikan), Universitas Negeri Surabaya, Surabaya.
Hsiao, Ju-Yuan, Chun-Ling Hung, Yu-Feng Lan, \& YoauChau Jeng. (2013). Integrating Worked Examples into Problem Posing in a Web-based Learning Environment. TOJET: The Turkish Online Journal of Educational Technology April 2013, volume 12.

Hobri. (2010). Metodologi Penelitian Pengembangan. Jember : Pena Salsabila.

Ibrahim, Muslimin, (2003). Pembelajaran Kooperatif. Surabaya: Unesa University Press.

Irwan. (2011). Pengaruh Pendekatan Problem Posing Model Search, Solve, Create, and Share (SSCS) dalam Upaya Meningkatkan Penalaran. Jurnal Penelitian Pendidikan Vol. 12 No. 1, April 2011.

Kasturi, Dafik, \& Ojat Darojat. (2015). Pengembangan Perangkat Pembelajaran Problem Posing Berorientasi Penerapan HOTS pada Materi Kesebangunan kelas IX @Pancaran, Vol. 4, No. 1, hal 11-32, Februari 2015.

Kesan, Cenk, Deniz Kaya, \& Selim Guvercin. (2010). The Effect of Problem Posing Approach to the Gifted Student's Mathematical Abilities. International Online Journal of Educational Sciences, 2010, 2 (3), 677-687.www.iojes.net.

Khabibah, Siti. (2006). Pengembangan Model Pembelajaran Matematika dengan Soal Terbuka untuk Meningkatkan Kreativitas Siswa Sekolah Dasar(Disertasi yang tidak dipublikasikan), Universitas Negeri Surabaya, Surabaya.

Kojima, Kazuaki, Kazuhisa Miwa, \& Tatsunori Matsui (2013). Supporting Mathematical Problem Posing with a System for Learning Generation Processes through Examples. International Journal of Artificial Intelligence in Education 22 (2013) 161-190.DOI 10.3233/JAI-130035.IOS Press.

Ma'rufi, Muhammad Ilyas, \& Fitriani A. (2014). Pengembangan Bahan Ajar Matematika Berbasis Problem Posing dengan Scaffolding Metakognitif pada SMPN Kota Palopo. Prosiding Seminar Nasional Volume 01, Nomor 1, Mei 2014.

Maryati. (2014). Keefektifan kooperatif think pair square (TPSQ) pada Materi Kubus, Balok, Prisma, dan Limas di SMP Kelas VIII SMP Negeri 1 Nganjuk (Tesis yang tidak dipublikasikan), Universitas Negeri Surabaya, Surabaya.

Muriadi, I Nengah Parta, \& Makbul Muksar. (2013). Pengembangan Perangkat Pembelajaran Matematika Tipe Problem Posing untuk Meningkatkan Penguasaan Konsep Operasi 
Bentuk Aljabar. 561, KNPM V, Himpunan Matematika Indonesia, Juni 2013.

Plomp, T. \& Nieveen, N. (2007). An Introduction to educational design Research. Shanghai : The East China Normal University.

Putra, Sitiatava Rizema. (2013). Desain Belajar Mengajar Kreatif Berbasis Sains. Yogyakarta: Diva Press.

Ratumanan, Tanwey Gerson \& Theresia Laurens. (2011). Penilaian Hasil Belajar pada Tingkat Satuan Pendidikan. Surabaya: Unesa University Press.

Saepudin, Aep, Babudin, Dedi Mulyadi, \& Adang. (2009). Gemar Belajar Matematika untuk SD/MI Kelas $V$. Jakarta: Pusat Perbukuan Depdikknas.

Saleh Haji. (2011). Pendekatan Problem Posing dalam Pembelajaran Matematika di Sekolah Dasar. Jurnal Kependidikan, Volume 14, No.1, April 2011.

Siswono, T.Y.E. (2008). Mengajar \& Meneliti Panduan Penelitian Tindakan Kelas untuk Guru dan Calon Guru. Surabaya: Unesa University Press.

Siswono, T.Y.E . (2008). Model Pembelajaran Matematika Berbasis Pengajuan dan Pemecahan Masalah untuk Meningkatkan Kemampuan Berpikir Kreatif. Surabaya: Unesa University Pres.

Slavin, Robert E. (1994). Educational Psychology: Theories and Practice (Four Edition). Boston: Allyn \& Bacon.

Subagyo, Mulyono \& YL Sukestiyarno. (2013). Pembelajaran Matematika Bermuatan Pendidikan Karakter dengan Pendekatan Problem Posing Melalui Laboratorium Teenzania. Unnes Journal of Mathematics Education Research, UJMER 2 (1) (2013).

Sugiono dan Gunarto, Dedi. (2009). Matematika SD/MI Kelas V. Jakarta: Pusat Perbukuan Depdiknas.

Trianto. (2007). Model Pembelajaran Terpadu dalam Teori dan Praktek. Jakarta: Prestasi Pustaka.

Undang- undang Sisdiknas. (2011). Yogyakarta: Pustaka Pelajar.

Upu, Hamzah. (2003). Problem Posing dan Problem Solving dalam Pembelajaran Matematika. Bandung: Pustaka Ramadhan.

Warsono \& Haryanto. (2012). Pembelajaran Aktif. Bandung: PT Remaja Rosdakarya.

Widnya, I Pt., Ign. I Wyn. Suwatra, \& I Nym. Murda. (2013). Implementasi Pendekatan problem posing untuk meningkatkan aktivitas dan hasil belajar matematika Siswa Kelas IV SD No.2

Banjar Bali. ejournal.undiksha.ac.id. 